УДК 342.341

DOI https://doi.org/10.32849/2663-5313/2019.11.36

\title{
Юрій Бурило,
}

докт. юрид. наук, доиент,

завідувач кафедри адміністративного права та процесу

ДВНЗ «Київський начіональний економічний університет імені Вадима Гетьмана»

\section{СУЧАСНИЙ РОЗВИТОК НАЦІОНАЛЬНОГО ЗАКОНОДАВСТВА ПРО КОРМИ}

У статті розглядаються питання наближення національного законодавства України про корми до законодавства Європейського Союзу, що здійснюється на виконання Угоди про асоціацію між Украӥною та Свропейським Союзом. Розглядаються основні регламенти СС, які регулюють питання безпечності, гігієни та маркування кормів, а також використання кормових добавок. Відзначається важлива роль простежуваності кормів для гарантування їх безпечності та розкриваються основні правові норм, шо регламентують простежуваність за приниипом «крок вперед» та «крок назад». Вказується на необхідність забезпечення простежуваності протягом усього харчового ланиюга. Висвітлюються основні приниипи НАССР та призначення иієї системи принагідно до забезпечення гігієни та безпечності кормів. Вказуються основні обов'язки операторів ринку кормів щодо запровадження НАССР. Пояснюється, в яких випадках дозволяється не запроваджувати НАССР та в яких випадках дозволяється спрощений підхід до НАССР. Розглядається сучасна система видачі експлуатаційних дозволів на потужності з виробниитва, змішування та приготування кормових добавок, преміксів і кормів. Розкриваються недоліки иієї системи. Зокрема, доводиться, що ия система створює надмірне регуляторне навантаження на бізнес. Стверджується, шо нова система видачі експлуатаційних дозволів та державної реєстрацї, передбачена Законом Украӥни «Про безпечність та гігієну кормів», яка побудована наєвропейськихпідходах, є більш прогресивною та сприятливою для господарюючих суб’єктів. Характеризується наявна в Україні система державної реєстраиії кормових добавок, преміксів і кормів. Звертається увага на те, що в Свропейському Союзі реєстрації підлягають лише кормові добавки. При цьому на відміну від Украӥни більшість кормових добавок у Свропейському Союзі реєструються без прив'язки до заявника. Наголошується на тому, що запровадження в Україні європейської моделі державної реєстрачій кормових добавок не лише дозволить зменшити бюрократичне навантаження на бізнес, а й допоможе операторам ринку кормів заощадити кошти на державній реєстрацї кормових добавок.

Ключові слова: наближення законодавства, корми, кормові добавки, потужності, Свропейський Союз, санітарні та фітосанітарні заходи.

Постановка проблеми. Укладення Угоди про асоціацію між Україною, з однієі сторони, та Європейським Союзом, Європейським співтовариством з атомної енергії і їхніми державами-членами, 3 іншої сторони, стало серйозним поштовхом для перегляду та модернізації національного законодавства України в багатьох сферах. Однією зі сфер, в яких Україна має наблизити своє законодавство до законодавства Європейського Союзу, є санітарні та фітосанітарні заходи (СФЗ). Такі заходи застосовуються всіма країнами світу $з$ метою захисту здоров'я людини, тварин та рослин. Водночас вони суттєво впливають на бізнес-клімат у кожній країні та її торговельні відносини 3 іншими країнами. 3 огляду на це, питанням гармонізації санітарних і фітосанітарних заходів спеціально присвячено главу 4 Розділу IV Угоди про асоціацію між Україною та ЄС [1].
Оскільки здоров'я людини напряму залежить від тих харчових продуктів тваринного походження, які вона споживає, значний вплив на її здоров'я справляють корми, що споживаються тваринами, з яких виробляють відповідні харчові продукти. У зв'язку 3 цим у законодавстві Свропейського Союзу детально регламентовані вимоги до гігієни та безпечності кормів та їх інгредієнтів. В Україні донедавна законодавче регулювання виробництва, обігу та використання кормів було досить поверхневим. Втім, прийняття у грудні 2017 року Закону України «Про безпечність та гігієну кормів» [2] обіцяє змінити ситуацію, оскільки спрямовує Україну на впровадження європейських вимог безпечності кормів.

Стан дослідження. Хоча окремі аспекти правового регулювання у сфері застосування санітарних та фітосанітарних заходів досліджувалися такими правознавцями, 
як В. І. Андріїв, А. І. Годяк, Є. М. Горовець, М. О. Дурсунов, Т. В. Оверковська, поза увагою наукової юридичної спільноти залишилися питання гармонізації національного законодавства України з питань безпечності та гігієни кормів з відповідним законодавством Європейського Союзу

Метою статті $€$ з'ясування основних новел, напрямів та проблем розвитку законодавства України про корми у світлі його наближення до відповідного законодавства Європейського Союзу.

Виклад основного матеріалу. Протягом тривалого часу суспільні відносини щодо забезпечення гігієни та безпечності кормів під час їх виробництва, обігу та використання в Україні регулювалися законодавством про ветеринарну медицину. Окремого закону, що регулював би відповідні питання, не було. Ситуація має невдовзі змінитися, оскільки в січні 2020 року набуде чинності Закон України «Про безпечність та гігієну кормів», прийнятий 21 грудня 2017 року, а норми чинного Закону України «Про ветеринарну медицину», що стосуються кормів, відійдуть у минуле.

Закон України «Про безпечність та гігієну кормів» грунтується на нормах трьох регламентів Європейського Союзу, а саме Регламенту ЄC № 183/2005, що визначає вимоги до гігієни кормів [3], Регламенту ЄC № 1831/2003 про використання добавок у харчуванні тварин [4] та Регламенту ЄС № 767/2009 про розміщення на ринку та використання кормів [5]. Кожен із цих регламентів закріплює окремий блок правил щодо виробництва, обігу та використання кормів, а саме: вимоги до гігієни, вимоги до безпечності кормів, що, зокрема, пов'язані 3 використанням кормових добавок, та вимоги до маркування, пакування та представлення кормів на ринку.

Крім того, в Законі України «Про безпечність та гігієну кормів» враховані загальні вимоги харчового законодавства Європейського Союзу, що містяться у Регламенті СС 178/2002, яким визначаються загальні принципи та вимоги харчового права, засновується EFSA (Свропейська Агенція з питань безпечності харчових продуктів), а також визначаються процедури забезпечення безпечності харчових продуктів [6].

Попри свою назву, в якій згадуються лише харчові продукти, насправді Регламентом ЄС 178/2002 також встановлюються загальні вимоги до безпечності кормів та діяльності операторів ринку кормів, тобто, по суті, закладаються основи законодавства ЄС про корми. Це пояснюється тим, що безпечність харчових продуктів у Свропейському Союзі та контроль за нею забезпечуються за принципом «від лану до столу» (from farm to fork). Іншими словами, для того, щоб гарантувати, що м'ясні та молочні продукти, яйця, мед та інші продукти тваринного походження є безпечними для людини, необхідно спочатку забезпечити та проконтролювати безпечність кормів, що згодовуються тваринам, від яких отримують відповідні продукти харчування. Саме тому базові принципи харчового законодавства також стосуються кормів та закріплені в одному й тому ж Регламенті СС.

Одним із фундаментальних принципів гарантування безпечності харчових продуктів і кормів є простежуваність. Відповідно до вимог ст. 18 Регламенту ЄС 178/2002 простежуваність кормів та будь-яких речовин, що включаються до їх складу, має бути забезпечена на всіх стадіях їх виробництва, переробки та обігу. При цьому кожен оператор ринку кормів має бути спроможний встановити особу, в якої він придбає та якій він реалізує корми та речовини, що включаються до їх складу (так звані «крок назад» та «крок вперед»). Зазначений принцип далі розвинуто в Регламенті ЄC $183 / 2005$, яким встановлені вимоги щодо документування операцій, що здійснюються з кормами та кормовими матеріалами, з метою забезпечення ï простежуваності. Відповідні європейські вимоги відображені в багатьох статтях Закону України «Про безпечність та гігієну кормів». Так, зокрема, у ст. 10, 12, 41 цього закону на операторів ринку покладається обов'язок застосовувати системи та процедури, що забезпечують можливість надання інформації щодо простежуваності корму на запит компетентного органу. Така інформація повинна зберігатися оператором ринку протягом шести місяців після закінчення мінімального строку зберігання корму. Так, зокрема, протягом зазначеного строку оператор ринку має зберігати товарно-транспортні накладні на корми, якщо він не застосовує інших методів забезпечення простежуваності. Крім цього, для забезпечення простежуваності кормів на операторів ринку також покладаються обов'язки наносити на пакування відповідне маркування, зберігати зразки кормових інгредієнтів та кожної партії вироблених і введених в обіг кормів. Вимоги щодо простежуваності є важливою передумовою забезпечення ефективності як державного контролю безпечності кормів, що здійснюється Державною службою України з питань безпечності харчових продуктів та захисту споживачів, так і корпоративного (внутрішнього) контролю, що здій- 
снюється виробниками кормів та іншими операторами ринку, які здійснюють їх обіг та використання.

Подібно до того як Законом України «Про основні принципи та вимоги до безпечності та якості харчових продуктів», прийнятого у 2015 році, на операторів ринку харчових продуктів було покладено обов'язок розробляти, вводити в дію та застосовувати постійно діючі процедури, що засновані на принципах системи аналізу небезпечних факторів та контролю у критичних точках (Hazard Analysis and Critical Control Points - НАCCР), а також забезпечувати належну підготовку свої працівників з питань застосування цих процедур, Закон України «Про безпечність та гігієну кормів» покладає аналогічний обов'язок на операторів ринку кормів.

Необхідно зазначити, що система НАССР є обов'язковою за законодавством більшості цивілізованих країн світу, таких як: країни Європейського Союзу, США, Канада, Японія, Нова Зеландія та інші. Ця система ідентифікує, оцінює та контролює небезпечні фактори, які є визначальними для безпеки харчових продуктів (кормів). Вона гарантуе безпечність продукції протягом усього харчового ланцюга і дає можливість виявити усі критичні точки, які можуть вплинути на безпечність кінцевого продукту, усунути шкідливі фактори і контролювати весь процес виробництва [7].

Разом із тим, враховуючи чималі витрати на впровадження НАССР для бізнесу, ст. 11 Закону України «Про безпечність та гігієну кормів» передбачає деякі послаблення та виключення із загального правила щодо обов'язковості цієї системи. Так, зокрема, відповідно до частини другої зазначеної статті не зобов'язані запроваджувати НАССР оператори ринку, що здійснюють первинне виробництво кормів, а також провадять пов'язану з первинним виробництвом діяльність, таку як транспортування, зберігання та поводження із первинною продукцією в місці первинного виробництва, транспортування первинної продукції 3 місця первинного виробництва до потужності, а також змішування кормів лише для потреб власного господарства без використання кормових добавок та преміксів, крім силосних кормових добавок. Іншими словами, для того щоб годувати худобу травою, скошеною на власному полі, запроваджувати НАССР не обов'язково.

Водночас частиною четвертою зазначеної статті передбачається можливість запровадження спрощеного підходу до НАССР, за умови що такий підхід забезпечує однаковий рівень захисту здоров'я тварин, що і в разі запровадження НАССР у повному обсязі, тобто $з$ урахуванням усіх семи принципів НАCCР, таких як: ідентифікація будь-яких небезпечних факторів, визначення критичних контрольних точок, встановлення критичних меж у критичних контрольних точках, запровадження процедур моніторингу в критичних контрольних точках, запровадження планів коригувальних дій, зберігання та актуалізація, оцінка результативності зазначених заходів, ведення та зберігання документів щодо НАССР. Запровадження спрощеного підходу до НАССР дасть змогу скоротити витрати на його запровадження насамперед для малого бізнесу.

3 метою створення організаційних передумов контролю безпечності кормів в Україні застосовується дозвільна процедура надання експлуатаційного дозволу, який фактично $є$ аналогом такого адміністративного інструменту, як “approval”, що застосовується в Європейському Союзі. Відповідно до ст. 50 чинного Закону України «Про ветеринарну медицину» на операторів ринку кормів покладається обов'язок отримувати експлуатаційний дозвіл на потужності з виробництва, змішування та приготування кормових добавок, преміксів і кормів.

Отже, з формально-юридичного погляду виявляється, що будь-яка січкарня або кормомішалка, а тим більше цех для приготування кормів на тваринницькій фермі вимагає отримання експлуатаційного дозволу. Більш того, навіть заготівля сіна на власному полі може бути кваліфікована як використання потужності 3 виробництва чи приготування кормів, оскільки під потужністю можна розуміти будь-яку земельну ділянку, будівлю, споруду тощо. При цьому експлуатаційний дозвіл на потужність може бути наданий лише за умови, що проведене на місці інспектування підтвердить відповідність цієї потужності ветеринарно-санітарним заходам, технічним регламентам та положенням Закону України «Про ветеринарну медицину». Якщо поряд із цим урахувати, що такий експлуатаційний дозвіл видається всього лише на один рік, то напрошується висновок про зайве і нераціональне регуляторне навантаження, а отже, необхідність проведення дерегуляції у цій сфері.

Проведення такої дерегуляції забезпечить Закон України «Про безпечність та гігієну кормів». Цим законом передбачені дві процедури: надання експлуатаційного дозволу на необмежений строк, що вимагає проведення попереднього інспектування, та державна реєстрація потужності, яка здійснюється за повідомним принципом. Екс- 
плуатаційний дозвіл буде необхідним лише для потужностей, які використовуються для виробництва та/або обігу деяких видів кормових добавок, преміксів і кормових сумішей (із використанням поживних, зоотехнічних та деяких інших кормових добавок).

У разі, якщо на потужності, призначеній для виробництва або обігу кормів, відповідні добавки не виробляються і не використовуються, вона просто підлягатиме державній реєстрації. При цьому основною перевагою державної реєстрації для суб'єктів господарювання $€$ те, що вона не вимагає проведення інспектування потужностей.

Водночас згідно з новим законом не вимагається ані експлуатаційний дозвіл, ані державна реєстрація потужностей у разі, якщо на них не відбувається виробництво або обіг, тобто реалізація або зберігання з метою реалізації кормів. Тому власники тваринницьких потужностей, на яких використовуються вже готові корми, не зобов'язані проходити жодних дозвільно-реєстраційних процедур, пов'язаних з юридичним оформленням цих потужностей.

Чимало уваги в Законі України «Про безпечність та гігієну кормів» присвячено регулюванню обігу та використання кормових добавок. Це пов'язано з тим, що для покращення споживчих характеристик сучасних кормів широко використовуються різноманітні добавки. При цьому кормові добавки можуть мати як позитивний, так і шкідливий вплив на здоров'я тварини або людини та навколишнє природне середовище. Тому для гарантування безпечності та ефективності кормових добавок у Європейському Союзі діє досить розвинуте законодавство, представлене насамперед Регламентом СС № 1831/2003. Основні положення цього Регламенту СС тепер відображені в Законі України «Про безпечність та гігієну кормів».

На відміну від чинної редакції Закону України «Про ветеринарну медицину», яка передбачає обов'язкову державну реєстрацію для кормових добавок, преміксів і готових кормів, Закон України «Про безпечність та гігієну кормів» передбачає державну реєстрацію лише кормових добавок. Це має значно спростити ведення бізнесу для виробників готових кормів, яким більше не доведеться реєструвати кожну рецептуру готового корму чи преміксу. Крім того, з точки зору бізнесу важливою перевагою європейської системи реєстрації кормових добавок є те, що кормові добавки більшості категорій реєструються без прив'язки до заявника. Такий європейський підхід, втілений у нормах Закону України «Про безпечність та гігієну кормів», дозволить усунути недосконалість чинного зако- нодавства України в цій сфері, згідно з яким одна й та сама кормова добавка підлягає державній реєстрації кожним суб'єктом господарювання, який має намір її використовувати. У результаті одна й та сама добавка може бути зареєстрована десятки разів на різних заявників. Варто відзначити, що така реєстрація не безкоштовна, оскільки вимагає проведення експертної оцінки, яка дорого коштує. Тому запровадження європейської системи державної реєстрації дозволить виробникам кормів суттєво заощадити, адже кормову добавку, зареєстровану за зверненням одного заявника, зможуть надалі використовувати всі інші господарюючі суб'єкти.

Ще одним способом заощадити на державній реєстрації кормових добавок може стати використання спрощеної системи державної реєстрації кормових добавок. Так, відповідно до ст. 19 Закону України «Про безпечність та гігієну кормів» спрощений порядок державної реєстрації застосовується до кормових добавок, які дозволені до використання іноземними державами або міжнародними організаціями (інтеграційними об'єднаннями держав) відповідно до вимог, що визнані Україною еквівалентними вимогам щодо державної реєстрації кормових добавок, встановленим законодавством України про корми. Суть такого спрощеного порядку зводиться до того, що для прийняття рішення про державну реєстрацію кормової добавки замість проведення наукової (експертної) оцінки кормової добавки Національною установою України з ветеринарних препаратів та кормових добавок використовується експертний висновок іноземної організації, яка здійснювала наукову оцінку (експертизу) відповідної кормової добавки. Таким чином усувається необхідність повторно проводити досить коштовну експертну оцінку безпечності та ефективності кормової добавки.

Водночас слід звернути увагу на те, що практична реалізація положень Закону України «Про безпечність та гігієну кормів» значною мірою залежатиме від вчасного прийняття цілої низки підзаконних нормативноправових актів, передбачених цим законом. Це пов'язано з тим, що законодавство про корми в Європейському Союзі є досить об'ємним. Тому для наближення національного законодавства України до законодавства Свропейського Союзу у цій сфері прийняття одного закону замало.

\section{Висновки}

Попри об'єктивні труднощі з наближенням національного законодавства України про корми до відповідного законодавства Європейського Союзу, в цілому цей процес 
має позитивний вплив як на розвиток національної правової системи, так і на посилення гарантій безпечності кормів для тварин, людей та навколишнього природного середовища. Крім того, здійснення такого наближення, як правило, має наслідком дерегуляцію та усунення зайвих бюрократичних механізмів, що сприятиме створенню кращих умов для ведення бізнесу в цій галузі.

Перспективи подалыших розвідок. Надалі наукові дослідження 3 окресленої тематики було б доцільно зосередити на питаннях правового регулювання маркування кормів у світлі вимог законодавства Європейського Союзу.

\section{Список використаних джерел:}

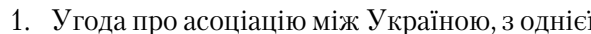
сторони, та Європейським Союзом, Європейським співтовариством з атомної енергії і їхніми державами-членами, з іншої сторони від 21.03.2014 р. та 27.06.2014 р. Офіиійний вісник Украӥни. 2014. № 75. Том 1. С. 83. Ст. 2125.

2. Про безпечність та гігієну кормів : Закон України від 21.12.2017 р. № 2264-VIII. Відомості Верховної Ради. 2018. № 10. Ст. 53.

3. Regulation (EC) No $183 / 2005$ of the European Parliament and of the Council of 12 January 2005 laying down requirements for feed hygiene.
URL : https://eur-lex.europa.eu/legal-content/EN/ ALL/?uri=CELEX\%3A32005R0183.

4. Regulation(EC)No1831/2003oftheEuropean Parliament and of the Council of 22 September 2003 on additives for use in animal nutrition. URL : https://eur-lex.europa.eu/legal-content/EN/ TXT/?uri=CELEX\%3A32003R1831

5. Regulation(EC) No 767/2009 of the European Parliament and of the Council of 13 July 2009 on the placing on the market and use of feed, amending European Parliament and Council Regulation (EC) No 1831/2003 and repealing Council Directive 79/373/EEC, Commission Directive 80/511/ EEC, Council Directives 82/471/EEC, 83/228/ EEC, 93/74/EEC, 93/113/EC and 96/25/ EC and Commission Decision 2004/217/EC. URL : https://eur-lex.europa.eu/legal-content/EN/ ALL/?uri=CELEX\%3A32009R0767

6. Regulation(EC) No 178/2002 of the European Parliamentand of the Council of 28January 2002laying down the general principles and requirements of food law, establishing the European Food Safety Authority and laying down procedures in matters of food safety. URL : https://eur-lex.europa.eu/legalcontent/EN/ALL/?uri=CELEX\%3A32002R0178

7. Трофимцева О. Внедрение НАССР в Украине необходимо для всех предприятий. URL : http://nvppoint.com/ru/vnedrenie-haccp-vukraine-neobhodimo-dlya-vseh-predpriyatiy/

The article deals with the approximation of the national legislation of Ukraine on feed to the relevant legislation of the European Union pursuant to the Association Agreement between Ukraine and the European Union. The EU's main regulations governing the safety, hygiene and labeling of feed, as well as the use of feed additives, are examined. The importance of traceability for ensuring the safety of feed as well as the basic legal rules "step forward" and "step back" governing traceability of feed are highlighted. The need for ensuring traceability throughout the food chain is emphasized. The basic principles of HACCP and the purpose of this system with regards to the safety and hygiene of feed are highlighted. The main responsibilities of feed market operators regarding the implementation of the HACCP system are outlined. It is further explained when the implementation of HACCP is not mandatory and when a simplified approach to the implementation of HACCP is allowed. The existing system of granting approvals for the production, mixing and preparation of feed additives, premixes and feeds is examined. The drawbacks of this system are revealed. In particular, it is stated that this system creates an excessive regulatory burden on business. It is also argued that the new system of granting approvals and state registration, provided for by the Law of Ukraine "On Feed Safety and Hygiene", which is based on the European model, is more advanced and favorable for businesses. The existing Ukrainian system of state registration of feed additives, premixes and feeds is characterized. It is pointed out that that only feed additives are subject to authorization in the European Union. Unlike Ukraine, the European Union authorizes feed additives without linking authorizations to specific holders. It is emphasized that the introduction of the European model of feed additives' authorization in Ukraine will help eliminate bureaucratic hurdles for business allowing feed market operators to save money on the state registration of feed additives.

Key words: approximation of legislation, feed, feed additives, establishments, the European Union, sanitary and phytosanitary measures. 